\title{
KEAMANAN, KESEHATAN DAN KESELAMATAN KERJA PETUGAS PENYIMPANAN DI RUMAH SAKIT X KOTA CIMAHI
}

\author{
Fizki Amelia Arsyah ${ }^{1}$, Siti Nurul Hidayah ${ }^{2}$, Leni Herfiyanti ${ }^{3}$ \\ Politeknik Piksi Ganesha, Bandung, Indonesia ${ }^{1,2,3}$ \\ faarsyah@piksi.ac.id ${ }^{1}$, snhidayah@ piksi.ac.id ${ }^{2}$, leniherfiyanti@ gmail.com ${ }^{3}$
}

Received: 11-07-2021

Revised : 24-07-2021

Accepted: 25-07-2021

\begin{abstract}
Abstrak
Latar Belakang: Penyimpanan adalah salah satu dari bagian unit rekam medis yang bertugas menyimpan menyediakan meretensi dan membantu dalam pelaksanaan pemusnahan rekam medis dalam meningkatkan sistem dan produktifitas kerja unit rekam medis maka keamanan, kesehatan dan keselamatan kerja sangat diutamakan. Berdasarkan observasi di Rumah Sakit X Kota Cimahi menunjukan keamanan, kesehatan dan keselamatan kerja pada petugas di ruangan penyimpanan belum efektif sehingga perlu dilakukannya evaluasi terhadap keamanan kesehatan dan keselamatan kerja diruang penyimpanan Rumah Sakit X Kota Cimahi.
\end{abstract}

Tujuan: Tujuan dari penelitian ini adalah untuk mengetahui keadaan ruang penyimpanan terhadap keamanan kesehatan dan keselamatan kerja bagi petugas penyimpanan di Rumah Sakit X Kota Cimahi.

Metode: Metode penelitian ini menggunakan deskriptif kualitatif. Subjek penelitian ini adalah 5 orang petugas penyimpanan. Objek yang diambil dalam penelitian ini yaitu ruangan penyimpanan. Teknik pengumpulan data dilakukan dengan wawancara dan observasi.

Hasil: Hasil penelitian ini diketahui bahwa di ruang penyimpanan Rumah Sakit X Kota Cimahi mengenai keamanan kesehatan dan keselamatan petugas penyimpanan belum efektif pada ukuran tinggi rak dan jarak antara rak yang sempit, ventilasi udara yang kurang, kardus yang tercecer dan kapasitas penuhnya rak sehingga dapat menimbulkaan resiko petugas terjatuh, pegal-pegal, tertimpa rekam medis, sesak nafas dan tersandung.

Kesimpulan: kesimpulan keadaan ruang penyimpanan terhadap keamanan, kesehatan dan keselamatan kerja bagi petugas penyimpanan di Rumah Sakit X Kota Cimahi masih menimbulkan faktor risiko kecelakaan kerja Ukuran Rak Penyimpanan yang kurang luas, Ukuran Rak Penyimpanan yang kurang luas, Rak terbuka yang terlalu tinggi.

Kata kunci: keamanan; kesehatan; keselamatan; petugas penyimpanan.

\footnotetext{
Abstract

Background: Storage is one of the parts of the medical record unit in charge of storing, providing retention and assisting in the implementation of the destruction of medical
} 
records in improving the system and work productivity of the medical record unit, so safety, health and safety are very important. Based on observations at the Cimahi City $X$ Hospital, it shows that the safety, health and safety of the officers in the storage room have not been effective, so it is necessary to evaluate occupational health and safety in the storage room of the Cimahi City X Hospital.

Objective: The purpose of this study was to determine the state of the storage room on occupational health and safety security for storage officers at Hospital X Cimahi City.

Methods: This research method uses descriptive qualitative. The subjects of this study were 5 storage officers. The object taken in this study is the storage room. Data collection techniques were carried out by interview and observation.

Results: The results of this study indicate that in the storage room of Hospital X Cimahi City regarding the health and safety of storage officers has not been effective in the size of the height of the shelves and the distance between narrow shelves, lack of air ventilation, scattered cardboard and the full capacity of the shelves so that it can cause the risk of officers falling, aches, hit by medical records, shortness of breath and tripping.

Conslusion: the conclusion of the state of the storage room on security, health and safety for storage officers at Hospital $X$ Cimahi City still poses a risk factor for work accidents. Keywords: security; health; safety; officer storage.

Coresponden Author : Fizki Amelia Arsyah Email : fizkiamelia2@gmail.com

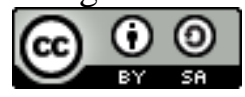

\section{PENDAHULUAN}

Menurut (Indonesia, 44 C.E.) Rumah sakit adalah instusi pelayanan kesehatan yang menyelenggarakan pelayanan kesehatan perorangan secara paripurna yang menyediakan pelayanan rawat inap, rawat jalan, dan gawat darurat. Setiap Rumah sakit mempunyai kewajiban memberikan informasi yang benar tentang pelayanan Rumah Sakit kepada masyarakat, memberi pelayanan kesehatan yang aman, bermutu antidiskriminasi, dan efektif dengan mengutamakan kepentingan pasien sesuai standar pelayanan Rumah Sakit dan menyelenggarakan Rekam Medis.

Menurut (Robi et al., 2021) Rekam Medis adalah berkas yang berisikan catatan dan dokumen tentang identitas pasien, pemeriksaan, pengobatan, tindakan dan pelayanan lain yang telah diberikan kepada pasien. Tujuan utama Rekam medis adalah untuk menunjang tercapainya tertib administrasi dalam mengupayakan peningkatatan pelayanan kesehatan di rumah sakit. Menurut (Robi et al., 2021) pasal 7 Sarana pelayanan kesehatan wajib menyediakan fasilitas yang diperlukan dalam rangka penyelenggaraan rekam medis. Maka dari itu sub unit yang mendukung penyelenggaran Rekam Medis adalah bagian penyimpanan. Penyimpanan adalah salah satu bagian dari unit rekam medis yang bertugas menyimpan rekam medis, menyediakan rekam medis, meretensi rekam medis, dan membantu dalam pelaksanaan pemusnahan rekam medis (Marlina, 2014). Penyimpanan bertanggung jawab terhadap penyimpanan rekam medis. Kecepatan 
penyedian rekam medis pada bagian peyimpanan mempengaruhi pelayanan terhadap pasien (Hakam, 2018).

Peran penting di bagian penyimpanan selain untuk penyimpanan Rekam Medis, bagian penyimpanan juga harus memperhatikan sistem kerja yang mengutamakan keamanan, kesehatan dan keselamatan dalam bekerja sehingga dapat mengurangi atau bebas dari kecelakaan kerja yang pada akhirnya dapat meningkatkan sistem dan produktifitas kerja, terutama pada saat pengambilan Rekam Medis (Simanjuntak \& Sirait, 2018).

Menurut (Salikunna \& Towidjojo, 2011) Kesehatan dan Keselamatan Kerja adalah upaya untuk memberikan jaminan keselamatan dan meningkatkan derajat kesehatan para pekerja/buruh denan cara pencegahan kecelakaan dan penyakit akibat kerja, pengendalian bahaya ditmpat kerja, promosi kesehatan, pengobatan dan rehabilitasi. Upaya Kesehatan dan Keselamatan kerja menyangkut tenaga kerja, cara/metode kerja, alat kerja, proses kerja dan lingkungan kerja.

Menurut (Rustiyanto \& Rahayu, 2011) lingkungan kerja merupakan tempat bekerja seseorang dalam melaksanakan segala aktivitasnya. Sebagai perekam medis, maka diperlukan ruang kerja rekam medis yang mencakup aspek ergonomi agar menimbulkan kenyamanan, kesehatan dan keselamatan kerja sehingga proses bekerja menjadi efisien dan efektif. Oleh karena itu penelitian ini dilaksanakan untuk mengetahui keadaan ruang penyimpanan terhadap keamanan kesehatan dan keselamatan kerja bagi petugas penyimpanan di Rumah Sakit X Kota Cimahi.

\section{METODE PENELITIAN}

Metode penelitian yang digunakan adalah penelitian deskriptif yaitu menggambarkan hasil penelitian sesuai dengan penelitian untuk menghasilkan gambaran sesuai dengan keadaan yang sebenarnya. Teknik pengumpulan data penelitian ini dengan wawancara dan observasi untuk mengetahui keefektivitasan petugas penyimpanan terhadap pengambilan rekam medis. Penelitian ini memusatkan diri secara intensif pada suatu obyek tertentu yang mempelajarinya sebagai suatu kasus. Data studi kasus diperoleh dari semua pihak yang bersangkutan. Subjek dalam penelitian ini terdiri dari 5 orang petugas penyimpanan di Rumah Sakit X Kota Cimahi dan Objek penelitian ini yaitu ruang penyimpanan Rumah Sakit X Kota Cimahi. Waktu penelitian dilaksanakan pada tanggal 26 April 2021 sampai dengan 26 Juni 2021.

\section{HASIL DAN PEMBAHASAN}

\section{A. Hasil Penelitian}

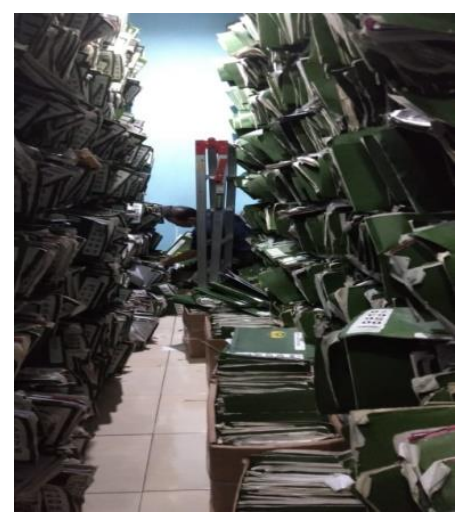

Gambar 1 Kondisi Ruang Penyimpanan Rumah Sakit X Kota Cimahi 
Berdasarkan hasil penelitian di Rumah Sakit X Kota Cimahi terdapat 3 ruang penyimpanan, seperti pada gambar 1 ruang penyimpanan rekam medis (filing) Sistem penyimpanan rekam medis di Rumah Sakit X Kota Cimahi menggunakan Sistem Sentralisasi di mana semua rekam medis pasien digabungkan dalam satu rekam medis dan satu tempat, baik untuk rawat jalan maupun rawat inap. Sistem penomoran rekam medis di Rumah Sakit X Kota Cimahi menggunakan Sistem Unit (Unit Numbering System) yaitu setiap kali pasien berkunjung ke Rumah Sakit X Kota Cimahi menggunakan satu nomor rekam medis. Sistem penjajaran rekam medis di Rumah Sakit X Kota Cimahi menggunakan sistem angka akhir (Terminal Digit Filing). Rumah Sakit X Kota Cimahi memppunyai 3 ruang penyimpanan dengan 99 rak.

Penulis telah melakukan pengamatan dan wawancara terhadap petugas penyimpanan terkait Keamanan, Kesehatan dan Keselamatan Kerja (K3). Adapun hasil pengamatan dan wawancara adalah sebagai berikut:

a) Jenis Rak Penyimpanan

Di ruang penyimpanan Rumah Sakit X Kota Cimahi menggunakan rak terbuka yang terbuat dari 2 jenis bahan rak penyimpanan yaitu dengan bahan baja dan alumunium.

b) Ukuran Rak Penyimpanan

Ukuran rak penyimpanan yang digunakan di ruang filing Rumah Sakit X Kota

Cimahi adalah panjang $240 \mathrm{~cm}$ tinggi $300 \mathrm{~cm}$ dan lebar $40 \mathrm{~cm}$.

c) Jarak Antara Rak Penyimpanan

Dari 3 ruangan jarak antara rak penyimpanan rekam medis di Rumah Sakit X Kota Cimahi di ruangan 1 adalah $100 \mathrm{~cm}$ dan di ruangan 2 dan ruangan 3 adalah $70 \mathrm{~cm}$.

d) Alat Bantu Pengambilan Rekam Medis

Alat Bantu di ruang penyimpanan Rumah Sakit X Kota Cimahi untuk pengambilan berkas rekam medis menggunakan tangga lipat.

e) Ventilasi

Di ruang penyimpanan Rumah Sakit X Kota Cimahi masih kurang ventilasi karena tertutup rak yang tinggi.

f) Muatan rak penyimpanan

Muatan rak rekam medis yang berlebihan kurang lebih berjumlah 300 rekam medis dalam per sub rak yang melebihi kapasitas.

g) Rambu dan Stiker Keamanan Kerja

Terdapat tanda peringatan "Selain Petugas Dilarang Masuk" di depan pintu ruang penyimpanan untuk menjamin kerahasiaan dan keamanan isi rekam medis.

h) Adanya Peralatan Untuk Penanganan Covid 19

Di ruang penyimpanan Rumah Sakit X Kota Cimahi tersedia peralatan peunjang untuk penanganan Covid 19 meliputi hand sanitaizer, disinfectan, masker dan face shiled.

i) Tersedia APAR

Di ruang penyimpanan Rumah Sakit X Kota Cimahi terdapat alat pemadam api ringan dan alarm sistem kebakaran pada setiap gedung atau ruangan.

\section{B. Pembahasan}

Keamanan kesehatan dan keselamatan kerja adalah pelindungan yang wajib diberikan oleh pihak pemberi kerja terhadap karyawannya. Menurut situs prodia OHI dijelaskan keamanan kesehatan dan keselamatan kerja merupakan salah satu upaya untuk menciptakan tempat kerja yang aman, sehat, bebas dari pencemaran lingkungan, sehingga dapat mengurangi dan atau bebas dari kecelakaan kerja dan penyakit akibat kerja yang 
pada akhirnya dapat meningkatkan efesiensi dan produktivitas kerja. Dan tujuan keamanan kesehatan dan keselamat kerja yaitu agar setiap pegawai mendapat jaminan keselamatan dan kesehatan kerja baik secara fisik, sosial dan pisikologis, perlengkapan dan peralatan kerja digunakan sebaik mungkin, terhindar dari gangguan kesehatan yang disebabkan lingkungan atas kondisi kerja dan pegawai merasa aman dan telindungi dalam bekerja. Adapun hasil penelitian di ruang penyimpanan Rumah Sakit X Kota Cimahi mengenai keamanan kesehatan dan keselamatan kerja petuugas penyimpanan sebagai berikut:

a) Jenis rak penyimpanan

Berdasarkan hasil wawancara dengan petugas penyimpanan rumah sakit $\mathrm{X}$ Kota Cimahi penggunaan rak terbuka sangat efektif karena memudahkan dalam pengambilan dan pengembalian rekam medis sehingga tidak memakan waktu.

Menurut (Rosita, 2019) rak terbuka lebih dianjurkan dengan alasan harga lebih murah dan lebih cepat dalam mengambil dan menyimpan rekam medis.

b) Ukuran rak penyimpanan

Berdasarkan wawancara di ruang penyimpanan rumah sakit $\mathrm{x}$ kota cimahi ukuran rak penyimpanan belum sesuai standar dan masih menimbulkan risiko kecelakaan kerja dan menurut salah satu petugas penyimpanan ukuran tinggi rak penyimpanan dulu adalah $200 \mathrm{~cm}$ tetapi karena kurangnya ruangan akhirnya tinggi rak ditambah menjadi $300 \mathrm{~cm}$ sehingga petugas menjadi sulit untuk menggambil dan mengembalikan rekam medis yang paling atas karena sulit terjangkau oleh tangan.

Hal ini sejalan dengan hasil penelitian (Hidayatul, 2018) bahwa standar/idealnya ukuran rak penyimpanan yaitu panjang $144 \mathrm{~cm}$ tinggi $190 \mathrm{~cm}$ lebar $40 \mathrm{~cm}$ sehingga dapat terjangkau oleh tangan dan tidak menimbulkan risiko kecelakaan kerja.

c) Jarak antara rak penyimpanan

Berdasarkan hasil observasi jarak antara rak penyimpanan di ruangan 1 sudah sesuai tetapi untuk ruangan 2 dan 3 belum sesuai standar hal tersebut dikarenakan kurangnya ruangan dan jumlah rak yang banyak yaitu 99 rak.

Menurut Depkes RI dan pernyataan Eka Wilda Faida bahwa jarak kosong antara dua rak rekam medis untuk lalu lalang petugas direkomendasikan berjarak $90 \mathrm{~cm}$ hal ini sesuai dengan hasil penelitian (Hidayatul, 2018) bahwa ukuran ideal jarak anatara rak yaitu 99,88 cm sedangkan di ruangan 2 dan 3 yaitu $70 \mathrm{~cm}$ sehingga menjadi sempit dan tidak efektif dan mengganggu gerak kerja petugas.

d) Alat Bantu Pengambilan Rekam Medis

Penggunaan Tangga lipat di ruang penyimpanan rumah sakit $\mathrm{x}$ kota cimahi belum efektif digunakan di ruang 2 dan 3 dikarenakan jarak rak yang sempit dan kardus yang tercecer dilantai sehingga tangga lipat susah di buka sempurna dan petugas untuk menjangkau rak yang tinggi terkadang memanjat ke rak. Sehingga menimbulkan risiko kecelakaan kerja seperti terjatuh dan tertimpa rekam medis.

e) Ventilasi

Menurut (Pandiangan et al., 2013) Ventilasi yang baik diperlukan diruangan kerja untuk meningkatkan kenyamanan dalam bekerja. Tetapi di ruang penyimpanan rumah sakit $\mathrm{x}$ kota cimahi ventilasi masih kurang dikarenakan tertutup rak rak yang tinggi sehingga mengakibatkan kekurangan sirkulasi udara atau oksigen yang akan menyebabkan sesak nafas, kelelahan, sakit kepala yang akan di alami oleh petugas rekam medis rumah sakit x kota cimahi.

f) Muatan rak penyimpanan

Berdasarkan hasil wawancara di ruang penyimpanan rumah sakit $\mathrm{x}$ per sub rak terisi 300 rekam medis sehingga melebihi kapasitas dikarenakan ruangan 
yang kurang dan rak yang tak menampung rekam medis sehingga sebagian rekam medis disimpan di dalam kardus kardus yang disimpan dilantai menyebabkan petugas berisiko tersandung atau terjatuh.

Menurut hasil penelitian (Irmawati et al., 2019)penggunaan rak penyimpanan yang terlalu penuh dapat mengakibatkan rak roboh dan ambruk dan memyulitkan petugas bagian filing kesulitan bekerja.

g) Rambu dan Stiker Keamanan Kerja

Menurut (Sitohang, 2019) Rambu larangan dan petunjuk arah untuk memindai dan memenuhi persyaratan kesehatan. Dan salah satu cara untuk menginformasikan kepada pekerja bahaya keslamatan dan kesehatan kerja.

h) Adanya peralatan penanganan covid 19

Menurut (Othman \& Ladiqi, 2021) di saat pandemi ini pegawai beraktivitas harus berhadapan dengan risiko terpaparnya virus corona (covid-19), oleh karena itu harus ada upaya menerapkan protokol kesehatan demi memutus rantai penularan covid-19.

Berdasarkan hasil observasi di ruang penyimpanan rumah sakit $\mathrm{x}$ kota Cimahi sudah menerapkan protokol kesehatan yaitu petugas memakai masker, face shiled, mencuci tangan atau menggunakan hand sanitaizer dan membersihkan ruangan dengan disenfectan.

i) Tersedia APAR

Dalam hal Kesehatan dan keselamatan kerja APAR merupakan alat wajib yang harus dilengkapi dalam mencegah terjadinya kebakaran yang dapat mengancam keselamatan pekerja.

\section{KESIMPULAN}

Berdasarkan dari hasil penelitian yang telah dilaksanakan, dapat ditarik kesimpulan keadaan ruang penyimpanan terhadap keamanan, kesehatan dan keselamatan kerja bagi petugas penyimpanan di Rumah Sakit X Kota Cimahi masih menimbulkan faktor risiko kecelakaan kerja. Ukuran Rak Penyimpanan yang kurang luas berdampak pada efektivitas gerak bekerja para petugas rekam medis rumah sakit kota x kota cimahi. Penggunaan rak penyimpanan yang terlalu penuh dapat mengakibatkan rak roboh atau ambruk, kardus yang tercecer dibawah rak yang dapat mengakibatkan petugas terjatuh, tersandung kardus tersebut dan kesulitan dalam bekerja.

Ventilasi yang kurang mengakibatkan terjadinya kekurangan sirkulasi udara atau oksigen yang akan menyebabkan sesak nafas, kelelahan, sakit kepala yang akan di alami oleh petugas rekam medis rumah sakit $\mathrm{x}$ kota cimahi. Rak terbuka yang terlalu tinggi menyulitkan petugas penyimpanan rumah sakit $\mathrm{x}$ kota cimahi dalam pengambilan rekam medis. Sehingga perlu dilakukannya evaluasi berkala terhadap keamanan kesehatan dan keselamatan kerja diruang penyimpanan Rumah Sakit X Kota Cimahi.

\section{BIBLIOGRAFI}

Hakam, f. (2018). Analisis penyediaan rekam medis pasien rawat jalan berdasarkan standar operasional prosedur (sop) di puskesmas x. Jurnal manajemen informasi dan administrasi kesehatan (jmiak), l(1).

Hidayatul, m. (2018). Tinjauan aspek ergonomi ruang filing berdasarka antropometri petugas filing terhadap kselamatan dan kesehatan kerja (k3) petugas di rs pku muhammadiyah yogyakarta. 
Indonesia, p. (44 c.e.). Undang-undang republik indonesia nomor 44 tahun 2009 tentang rumah sakit.

Irmawati, i., kresnowati, 1., susanto, e., \& nurfalah, t. I. (2019). Kesehatan dan keselamatan kerja (k3) di bagian filing. Jurnal manajemen informasi kesehatan indonesia (jmiki), 7(1), 38.

Marlina, e. V. I. (2014). Tinjauan pelayanan rekam medis bagian filing di puskesmas bejen kabupaten temanggung tahun 2014. Eprints. Dinus. Ac. Id.

Othman, m. F., \& ladiqi, s. (2021). Good party governance: praktik partai politik di indonesia dan malaysia dalam tata kelola pemerintahan yang baik. Gerhana publishing.

Pandiangan, k. C., huda, 1. N., \& rambe, a. J. M. (2013). Analisis perancangan sistem ventilasi dalam meningkatkan kenyamanan termal pekerja di ruangan formulasi $\mathrm{pt}$ xyz. Jurnal teknik industri usu, l(1), 219148.

Robi, h., maiyestati, m., \& zarfinal, z. (2021). Implementasi peraturan menteri kesehatan republik indonesia nomor 269 tahun 2008 tentang rekam medis terhadap klaim bpjs di rsud sungai dareh. Universitas bung hatta.

Rosita, r. R. (2019). Perencanaan desain rak penyimpanan dokumen rekam medis berdasarkan antropometri. Profesi (profesional islam): media publikasi penelitian, 17(1), 14-22.

Rustiyanto, e., \& rahayu, w. A. (2011). Manajemen filing dokumen rekam medis dan informasi kesehatan. Yogyakarta: politeknik kesehatan permata indonesia.

Salikunna, n. A., \& towidjojo, v. D. (2011). Penerapan sistem manajemen kesehatan dan keselamatan kerja di rumah sakit bersalin pertiwi makassar. Biocelebes, 5(1).

Simanjuntak, e., \& sirait, 1. W. O. Menkes. Ri. (2018). Faktor-faktor penyebab terjadinya missfile di bagian penyimpanan berkas rekam medis rumah sakit mitra medika medan tahun 2017. Jurnal ilmiah perekam dan informasi kesehatan imelda (jipiki), $3(1), 370-379$.

Sitohang, d. (2019). Penerapan manajemen k3 di rumah sakit.

(C) 2021 by the authors. Submitted for possible open access publication under the cc) (7) (2) terms and conditions of the Creative Commons Attribution (CC BY SA) license (https://creativecommons.org/licenses/by-sa/4.0/). 